\title{
The Role of the School Library and the School Librarian in the Context of New Curricula: Croatian Case
}

Ivana Perić

iprelasperic@gmail.com

The Primary School Petra Preradovića, Zadar.

Danijela Riger-Knez

danijelaknez@gmail.com

The Vocational School for Tourism and Catering, Zadar.

\section{Tanja Telesmanić}

tanja.telesmanic@skole.hr

The Vocational School for Economics, Administration and Trade Zadar.

Hajdi Škarica

skaricah@gmail.com

The High School Franje Petrića Zadar.

\section{Mišela Nežić}

misela.grmic@skole.hr

The Primary School Zadarski Otoci, Zadar.

Keywords: school librarian, library programme framework, information and media literacy education and promoting reading programme, educational role of school librarian, new curricula in the Republic of Croatia

\section{Abstract}

Concerning the development and the opportunities provided by new technologies and changes in social reality, the task of educational staff is to raise and educate responsible participants in the learning process adaptable to new situations of learning in the digital age, the age of vast information, and therefore be prepared for life-long learning. As school librarians are recognised as educated and essential collaborators in this task, which is common to all educational staff, it is necessary to operationalise their role in the educational system in Croatia and encourage development of new curricula. 
This paper proposes a framework for a programme, which has a starting point in new subject curricula and extra-curricula topics.

It starts from the constructivist approach of teaching where at the core are students who do not memorize facts but are capable of solving problems through active research and interaction with information and thus creating new knowledge. This approach encourages students to be critical thinkers, express themselves freely, be creative and strengthen their confidence in their quest to acquire competencies that develop the proposed framework for a library programme in information and media literacy education, and promoting reading.

\section{Introduction}

The $21^{\text {st }}$ century school library as an "information, media and communication centre of the school" (Ministry of Science, Education and Sports [MZO], 2006, p. 19), and the qualified school librarian ${ }^{1}$, as an educator and information specialist, provides support and assistance to students and teachers in independent, conscious, creative and responsible learning and vocational training. The school librarian also helps them in the development of generic competencies listed in the European reference framework of 2006, focusing on the digital competences and learning how to learn as the key competencies. Learning how to learn or knowing how to learn is one of the preconditions for lifelong learning. The school librarian in cooperation with teachers encourages the development of skills to organise learning, management of learning, problem solving, acceptance, processing and evaluation of information and their integration into meaningful units of new knowledge and skills that are applicable in different situations. With the current reform changes in primary and secondary education in the Republic of Croatia ${ }^{2}$, space is created for the school librarians to introduce qualitative changes in educational work, create programmes of librarian specific educational work, which include the promoting reading and library usage, information and media literacy in both the printed and digital environments. These qualitative changes are only a continuation of their previous efforts. In the framework of its educational activities for many years, Croatian school librarian's community questions the need for systematic teaching of students and teachers in information literacy as the basis of lifelong learning.

In this paper the authors will indicate the strategic documents that preceded the curricular reform in which school librarians are more clearly positioned as indispensable teachers and professional associates in achieving educational outcomes and expectations in most subject curricula and cross-curricular topics. In this context, it will be shown how the vision of the school librarian was altered from The Curriculum for Primary Schools in 2006 to the new 2019 curricula, and the circumstances that led to the development of the proposal for the framework in teaching library, information and media literacy and reading promotion (library, information, media literacy education and promoting reading [KIMP]). ${ }^{3}$

\section{The school library in the context of new learning and teaching strategies}

Until the changes that resulted in the introduction of the Croatian National Education Standard [HNOS] and The Curriculum for Primary Schools in 2006 (Vican \& Milanović Litre, 2006), the Croatian

\footnotetext{
${ }^{1}$ University degree in Librarianship (Information sciences) with teaching competences gained at University study, or teaching competences gained by any other form of study programme and teaching, or special programme with teaching competences.

${ }^{2}$ Curricular reform - experimental programme School for Life held in some schools through 2018/2019 school year; new curricula and cross-curricular topics in 2019; frontal implementation of curricular reform in all schools from 2019/ 2020 school year.

${ }^{3}$ In this paper authors use the term library programme framework, information and media literacy education and promoting reading programme. It covers the areas of library literacy, information literacy, media literacy and the promotion of reading in primary and secondary schools in the Republic of Croatia. Hereinafter, the abbreviation KIMP will be used for this programme framework.
} 
education system was characterised by content focused learning of the prescribed curriculum. With HNOS, the system was modernised only for primary education moving from content focused learning and what the teacher is doing to educational outcomes. In those circumstances, information literacy was included in primary schools, through the work of the school librarian, as a library-information content [KIP]. Since the changes in the educational system are not taking place simultaneously at all levels, from primary education to secondary, and noting the need to continue the systematic library and information literacy education, in secondary schools it is carried out informally, i.e. the decision of some high school librarians who, at their sole discretion, undertook teaching students library and information literacy (Stričević \& Perić, 2019). Ten years later a group of school librarians created a programme framework for Library-Information and Media Education in secondary and vocational schools [KIMOO] as an extension to the programme for primary schools that was suitable for high schools, which aimed to standardise practices across all educational vertical levels (Telesmanić, Grbić, Riger-Knez \& Perić, 2017).

In the period from 2006 to 2019 several strategic documents appeared in the field of education. They gave guidelines for the modernisation of the teaching process in which the school librarian was able to find a place for his activities. Furthermore, the National Curriculum Framework for Preschool Education, General Compulsory and Secondary Education [NOK] was published in 2010. This document provides a framework for the acquisition of basic competencies that will prepare students for lifelong learning. NOK was based on the fact that we live and work in a society that requires new knowledge, skills, abilities, values and attitudes, focused on the development of innovation, creativity, problem solving, critical thinking, entrepreneurship, computer literacy and social skills. Such competencies were impossible to achieve in the traditional educational system, which operates exclusively as a means of transferring knowledge. Therefore, a shift was made in creating curricula with a complete switch in the approach towards planning and programming of the education process: instead of transferring the knowledge, to be focused on the development of competences (Ministry of Science, Education and Sports, 2010). The Educational policy in the Republic of Croatia then accepted the eight key competencies listed in the European Reference Framework of 2006, namely: communication in the mother tongue, communication in foreign languages, mathematical competence and basic competences in natural sciences and technology, digital competence, learning how to learn, social and citizenship competence, initiative and entrepreneurship and cultural awareness and expression. NOK was designed as a developmental document planned to be followed by other elaborated documents, which would create new curricula for all school subjects and cross-curricular topics, but that process did not happen until 2019.

In 2014, The Strategy of Education, Science and Technology (Government of the Republic of Croatia, 2014) was adopted. In October 2017 another important strategic document applicable to the creation of curricula for school libraries was also adopted - National Reading Strategy for the period 2017-2022 (Ministry of Culture, 2017). That document had some objectives in correlation with the above-mentioned Strategy, and in the elaboration of its strategic goals predicted new curricula. However, 29 subject curricula and seven cross-curricular topic curricula were adopted in January and March 2019, and they created a new educational environment. In new curricula, the school library is recognised as an important collection of resources of information in all media and the place for cooperation and collaborative work of librarians and teachers, but librarians still need to be clearly positioned as an inseparable part of the educational process.

Until this moment, the school libraries did not get their own curriculum, as was the case with the Slovenian school libraries (Steinbach, 2010). Therefore, they need to develop their own programmes, which will include the school library and the school librarian in the process of teaching and learning,

International Association of School Librarianship

https://iasl-online.org 
incorporate those activities in the school curriculum and the annual operating plans of the curriculum subjects. Considering the content of new curricula, it is obvious that the inclusion of the school library and the school librarian in the educational process is necessary in order to achieve the intended outcomes of the subject curricula and cross-curricular topics regarding the promoting reading and information and media literacy education of students, as well as in the professional development of teachers.

\section{The purpose and description of the framework for the library, information and media literacy and promoting reading programme (KIMP)}

In addition to the above-mentioned key competencies, this programme is meant to develop competencies in four key areas. Specifically, this includes library, information and media literacy, with a focus on research teaching and promoting reading in primary and secondary schools. The aim of this paper is not a theoretical determination of certain areas, which is in the scientific community still subject to debate, but it is based on the fundamental understanding of the above literacies and recommendations for their implementation in education as required by the IFLA and UNESCO. According to them, the key learning activities, that are aimed at school librarians, are promoting literacy and reading, teaching media and information literacy, research teaching, integration of technology and teacher education (Schultz-Jones \& Oberg, 2016).

Library literacy refers to the competent use of libraries. Library competences are acquired by the introduction and teaching about the use of the library, its services and resources (Špiranec \& Banek Zorica, 2008). Although the term library literacy in Croatia has not taken hold as an independent concept, it appears as a library-information area [KIP] in the context of school libraries and education of library users (Vican \& Milanović Litre, 2006).

Information literacy in this context is understood as literacy in various levels so that students can recognize and articulate information need, use different sources of information, critically access and evaluate them and apply ethically selected information by creating new and their own content. In fact, students who interact more autonomously with information do not memorise facts through lectures but learn through active research, critical thinking and constructing new knowledge which results in better competencies in solving problems (Lau, 2011).

Furthermore, media literacy is based on the ability to access media on a personal level, the ability to analyse it according to certain criteria, the evaluation based on the previous analysis and, finally, independently creating media content. Media literacy education, as mentioned in the Media Literacy Fundamentals Canada's Center for Digital and Media Literacy, involves a lengthy process during which the student becomes media literate, and is able to understand the nature, techniques and influence of the media messages and their allied products in daily life.

Promoting reading, as one of the areas of the programme, is particularly important because its implementation encourages the development of lifelong readers, reading for the sake of learning and pleasure, and the development of critical thinking. Recognised as important for the development of all key competencies, promoting reading is crucial for expanding literacy in their native language and thus lifelong learning. Promoting reading is carried out in the framework of educational, cultural and public activities of the school library and it includes students, teachers, professional staff, parents, writers, cultural employees, stakeholders and members from the local community.

International Association of School Librarianship

https://iasl-online.org 
Therefore, the framework for the programme KIMP contains all of these fields: library literacy, information literacy, media literacy and promoting reading which make them a basis for lifelong learning.

\subsection{Connection with other subjects and cross-curricular topics}

The afore mentioned areas in the framework programme KIMP can be recognised in the new subject curricula (e.g. Informatics, Nature, Nature and Society, Biology, History, etc.), and materialized within curricula subjects Croatian language (Ministry of Science and Education [MZO], NN 10 / 2019, 214, 215), foreign languages (MZO, NN 7/2019, 135; MZO, NN 10/2019, 124), Geography (MZO, NN $7 / 2019,145)$, and the curriculum of cross-curricular topics Learning to Learn (MZO, NN 7/2019, 154) and Information and Communication Technology (MZO, NN 7/2019, 150).

The proposed educational outcomes of KIMP are common outcomes of individual subject curricula and expectations of the extra-curriculum topics:

- library literacy and cooperation with the school library appears in the curriculum of the Croatian language within the domain B Literature and creativity and domain C Culture and the Media - information literacy and cooperation with the school library appears in the subject curricula: Croatian language within the domain A Croatian language and communication, domain B Literature and creativity and domain C Culture and media; Informatics in domain A Information and digital technology, domain C Digital literacy and communication, domain D E-society; Geography in the domain B Environment processes; foreign languages within the domain $\mathrm{C}$ Autonomy in the acquisition of language; cross-curricular curriculum Learning to learn in the domain A Application of learning strategies and information management; Use of information and communication technologies in the domain A Functional and responsible use of ICT, the domain B Communication and collaboration in the digital environment, domain $\mathrm{C}$ Research and critical evaluation in the digital environment

- media literacy occurs in the subject curriculum of the Croatian language within the domain C Culture and Media

- encourage reading and cooperation with the school library appears in the curriculum Croatian language within the domain B Literature and creativity and domain C Culture and the media; in the curriculum of foreign languages within the domain B Intercultural communicative competence.

\section{Objectives, content and educational outcomes of KIMP in the educational vertical from first} to fifth cycle (1st grade Elementary school until 4th grade High school)

The aim of the implementation of KIMP is for the students to be IT literate, independent learners, ready to continue education and lifelong learning and develop reading skills, strategies and habits at the end of secondary education. The programme is divided and developed into five educational cycles, which follow the structure of subject curricula and curricula of cross-curricular topics in classes. 
Aims and contents of KIMP in the first cycle (1st and 2nd grade Elementary school)

\begin{tabular}{|c|c|c|}
\hline Specific objectives & Contents & Outcomes / Expectations \\
\hline $\begin{array}{l}\text { Students will: } \\
\text { explain what a library is, } \\
\text { where it is located in school } \\
\text { and familiarise themselves } \\
\text { with the parts intended for } \\
\text { users } \\
\text { request information with the } \\
\text { help of the librarian } \\
\text { behave according to the rules } \\
\text { of conduct in the school } \\
\text { library }\end{array}$ & $\begin{array}{l}\text { The school library } \\
\text { The school library space, } \\
\text { freely accessible material, } \\
\text { student fund, teachers' fund, } \\
\text { reading space, the library } \\
\text { desk, the library as a } \\
\text { multifunctional space } \\
\text { The librarian as an } \\
\text { information resource } \\
\text { Library organisation, dealing } \\
\text { with the book }\end{array}$ & $\begin{array}{l}\text { The student: } \\
\text { distinguishes the library from } \\
\text { other institutions; } \\
\text { distinguishes the library from } \\
\text { the bookstore } \\
\text { independently comes to the } \\
\text { school library } \\
\text { know the library space and its } \\
\text { layout } \\
\text { freely addresses the librarian } \\
\text { when he or she needs } \\
\text { information or help } \\
\text { experiences the library as a } \\
\text { space for all users } \\
\text { realises his/hers own rights } \\
\text { and respects the rights of } \\
\text { others }\end{array}$ \\
\hline $\begin{array}{l}\text { familiarise themselves with } \\
\text { the borrowing procedure of } \\
\text { library materials }\end{array}$ & $\begin{array}{l}\text { Library opening hours, the } \\
\text { use of materials in the } \\
\text { library, borrowing materials } \\
\text { for use at home, membership } \\
\text { card, parts of books }\end{array}$ & $\begin{array}{l}\text { uses the library and respects } \\
\text { the rules of library use }\end{array}$ \\
\hline $\begin{array}{l}\text { familiarise themselves with } \\
\text { basic library services }\end{array}$ & $\begin{array}{l}\text { Using materials within the } \\
\text { library, borrowing library } \\
\text { materials, help in finding } \\
\text { items, search for information } \\
\text { and resolve requests for } \\
\text { information, getting } \\
\text { acquainted with new titles, } \\
\text { reservation of library } \\
\text { materials, the use of ICT, use } \\
\text { of appropriate online sources } \\
\text { for children, participation in } \\
\text { events and activities in the } \\
\text { school library }\end{array}$ & uses basic library services \\
\hline
\end{tabular}









\begin{tabular}{|c|c|c|}
\hline & & $\begin{array}{l}\text { uses author and title } \\
\text { information to identify and } \\
\text { locate the source }\end{array}$ \\
\hline $\begin{array}{l}\text { be creative encouraged by } \\
\text { literature and respect others' } \\
\text { work }\end{array}$ & $\begin{array}{l}\text { Creating a picture book } \\
\text { Copyright }\end{array}$ & $\begin{array}{l}\text { uses the library as a place for } \\
\text { creative work stimulated by } \\
\text { reading } \\
\text { presents his work } \\
\text { recognises and describes the } \\
\text { concept of copyright }\end{array}$ \\
\hline $\begin{array}{l}\text { determine the main features } \\
\text { of product placement in the } \\
\text { most watched television-slots }\end{array}$ & $\begin{array}{l}\text { Product placement } \\
\text { recognition in easy } \\
\text { entertainment programmes }\end{array}$ & $\begin{array}{l}\text { recognises product placement } \\
\text { in popular TV programmes } \\
\text { and understand their role }\end{array}$ \\
\hline $\begin{array}{l}\text { recognize hidden advertising } \\
\text { in animated films }\end{array}$ & $\begin{array}{l}\text { Hidden animated film } \\
\text { advertising }\end{array}$ & $\begin{array}{l}\text { describes examples of covert } \\
\text { advertising in animated films. }\end{array}$ \\
\hline
\end{tabular}

Aims and contents of KIMP in the second cycle (3rd, 4th, and 5th grade Elementary school)

\begin{tabular}{|c|c|c|}
\hline Specific objectives & Contents & Outcomes / Expectations \\
\hline $\begin{array}{l}\text { Students will: } \\
\text { get to know the process of } \\
\text { how a book is created; } \\
\text { understand the path of the } \\
\text { book from author to reader }\end{array}$ & $\begin{array}{l}\text { Author, manuscript, editor, } \\
\text { translator, illustrator, } \\
\text { proof-reader, printing press, } \\
\text { publishing house, bookstore, } \\
\text { publishing catalogue, online } \\
\text { bookstore, book fair }\end{array}$ & $\begin{array}{l}\text { The student: } \\
\text { understands the value of } \\
\text { creative achievement in creating } \\
\text { a work } \\
\text { understands the contribution of } \\
\text { individual organisations in the } \\
\text { dissemination of knowledge }\end{array}$ \\
\hline $\begin{array}{l}\text { expand the use of library } \\
\text { services and materials } \\
\text { introduce the library as a } \\
\text { multicultural and democratic } \\
\text { space }\end{array}$ & $\begin{array}{l}\text { Use of print and online } \\
\text { spellings and dictionaries } \\
\text { through links on the library's } \\
\text { website } \\
\text { Library material for specific } \\
\text { user groups }\end{array}$ & $\begin{array}{l}\text { uses basic library services } \\
\text { uses online library services } \\
\text { uses materials according to } \\
\text { needs and capabilities }\end{array}$ \\
\hline
\end{tabular}




\begin{tabular}{|c|c|c|}
\hline $\begin{array}{l}\text { learn ways to create different } \\
\text { content and develop } \\
\text { creativity }\end{array}$ & $\begin{array}{l}\text { Placard, poster, comic book, } \\
\text { song, presentation, private } \\
\text { and public release of content }\end{array}$ & $\begin{array}{l}\text { uses different ways of creating } \\
\text { content } \\
\text { publishes them on the library's } \\
\text { website }\end{array}$ \\
\hline $\begin{array}{l}\text { learn about the positive role } \\
\text { of the media and the impact } \\
\text { of negative media content on } \\
\text { children }\end{array}$ & $\begin{array}{l}\text { Positive and negative media } \\
\text { content }\end{array}$ & $\begin{array}{l}\text { develops the habit of critically } \\
\text { questioning media content } \\
\text {. uses educational media content }\end{array}$ \\
\hline $\begin{array}{l}\text { become aware of the positive } \\
\text { and negative sides of the } \\
\text { internet and identify safe } \\
\text { ways to use it }\end{array}$ & Child safety online..$^{5}$ & $\begin{array}{l}\text { proposes and follows guidelines } \\
\text { for the safe use of the Internet } \\
\text { and social networks }\end{array}$ \\
\hline $\begin{array}{l}\text { differentiate between } \\
\text { different types of library } \\
\text { materials }\end{array}$ & $\begin{array}{l}\text { Newspapers, magazines, } \\
\text { books, photos, manuscripts, } \\
\text { music publications, audio } \\
\text { books, DVDs, CDs... }\end{array}$ & $\begin{array}{l}\text { selects specific types of library } \\
\text { material according to purpose }\end{array}$ \\
\hline $\begin{array}{l}\text { differentiate material by } \\
\text { purpose and learn about } \\
\text { different types of } \\
\text { information sources } \\
\text { get to know the basic criteria } \\
\text { for evaluating online } \\
\text { information sources }\end{array}$ & $\begin{array}{l}\text { Primary and secondary } \\
\text { sources of information, } \\
\text { experts, institutions, } \\
\text { libraries, museums, theatres, } \\
\text { reference materials: } \\
\text { lexicons, encyclopaedias, } \\
\text { dictionaries, maps, atlases, } \\
\text { bibliographies, catalogues, } \\
\text { internet ... }\end{array}$ & $\begin{array}{l}\text { uses primary and secondary } \\
\text { sources of information } \\
\text { uses reference material as a } \\
\text { credible source of information } \\
\text { needed } \\
\text { critically evaluates online } \\
\text { resources to obtain day-to-day } \\
\text { information }\end{array}$ \\
\hline $\begin{array}{l}\text { learn the steps of simple } \\
\text { research when solving } \\
\text { problems }\end{array}$ & $\begin{array}{l}\text { Solving problems and } \\
\text { making decisions using } \\
\text { information literacy model } \\
\text { Super } 3^{6}\end{array}$ & $\begin{array}{l}\text { applies models for developing } \\
\text { information literacy } \\
\text { exercises research and problem } \\
\text { solving }\end{array}$ \\
\hline
\end{tabular}

\footnotetext{
${ }^{4}$ A large selection of content for students in grades 1-4 on the Media Literacy website. Available at https://www.medijskapismenost.hr/wp-content/uploads/2018/04/pozitivni-i-negativni-med-sadrzaj.pdf

${ }^{5}$ A large selection of content for students in grades $5-8$ on the Media Literacy website. Available https://www.medijskapismenost.hr/wp-content/uploads/2018/04/elektronicko-nasilje.pdf

${ }^{6}$ Super 3 is a BIG 6 model, an information literacy model tailored to young children. More information: The BIG 6: Information and Technology Skills For Student Success. https://thebig6.org/
} 


\begin{tabular}{|c|c|c|}
\hline $\begin{array}{l}\text { become familiar with the } \\
\text { ethical use of other people's } \\
\text { work }\end{array}$ & $\begin{array}{l}\text { Copy paste, theft } \\
\text { (downloading music, films, } \\
\text { games, homework, } \\
\text { presentations without the } \\
\text { permission of the author) }\end{array}$ & $\begin{array}{l}\text { respects the copyright when } \\
\text { using other works, uses } \\
\text { permitted content } \\
\text { respects copyright when } \\
\text { creating content }\end{array}$ \\
\hline $\begin{array}{l}\text { get acquainted with specific } \\
\text { sources for particular } \\
\text { sciences }\end{array}$ & $\begin{array}{l}\text { Areas of human knowledge } \\
\text { (e.g. according to UDC) } \\
\text { Relationship of educational } \\
\text { material with teaching } \\
\text { subjects }\end{array}$ & $\begin{array}{l}\text { uses instructional resources to } \\
\text { seek information and learn }\end{array}$ \\
\hline $\begin{array}{l}\text { will be introduced to the } \\
\text { basic bibliographic } \\
\text { information needed to find } \\
\text { the source of the information } \\
\text { get to know the organisation } \\
\text { of information in a catalogue } \\
\text { and use it to inform the } \\
\text { availability of sources } \\
\text { use the signature to search } \\
\text { for library material in free } \\
\text { access } \\
\text { read literature for personal } \\
\text { growth and pleasure }\end{array}$ & $\begin{array}{l}\text { Short bibliographic } \\
\text { description: author, title, } \\
\text { place of publication, } \\
\text { publishing house, year of } \\
\text { publication } \\
\text { Search the library catalogue } \\
\text { according to different } \\
\text { criteria: author, title, year of } \\
\text { publication, keywords, } \\
\text { subject, UDC } \\
\text { Layout of professional } \\
\text { material on shelves (basic } \\
\text { UDC groups) } \\
\text { Artistic literature }\end{array}$ & $\begin{array}{l}\text { uses a library catalogue to query } \\
\text { the availability of sources } \\
\text { finds material in free access } \\
\text { after using the catalogue } \\
\text { actively engages in critical, } \\
\text { creative reading and the } \\
\text { purposeful use of sources } \\
\text { participates in various activities } \\
\text { to encourage reading }\end{array}$ \\
\hline $\begin{array}{l}\text { become more familiar with } \\
\text { copyright and its protection }\end{array}$ & $\begin{array}{l}\text { Copyright, plagiarism, } \\
\text { piracy, the copyright sign, } \\
\text { Creative Commons licenses }\end{array}$ & $\begin{array}{l}\text { explains copyright and } \\
\text { ownership } \\
\text { respects copyrights when using } \\
\text { someone else's content and } \\
\text { creating their own content } \\
\text { lists copyright infringement } \\
\text { procedures }\end{array}$ \\
\hline
\end{tabular}




\begin{tabular}{|c|c|c|}
\hline $\begin{array}{l}\text { learn how to identify product } \\
\text { promotion in YouTube posts }\end{array}$ & $\begin{array}{l}\text { Promotion of products in } \\
\text { posts on You Tube }\end{array}$ & $\begin{array}{l}\text { recognises product promotion in } \\
\text { the posts of well-known } \\
\text { Croatian youtubers }\end{array}$ \\
\hline $\begin{array}{l}\text { analyse the main models of } \\
\text { hidden ads in youth } \\
\text { magazines }\end{array}$ & $\begin{array}{l}\text { Identifying hidden } \\
\text { advertising in youth } \\
\text { magazines }\end{array}$ & $\begin{array}{l}\text { recognises the main sections in } \\
\text { which the advertisements are } \\
\text { placed }\end{array}$ \\
\hline $\begin{array}{l}\text { develop critical thinking } \\
\text { when sharing content online }\end{array}$ & $\begin{array}{l}\text { Identifying misleading } \\
\text { internet advertising }\end{array}$ & $\begin{array}{l}\text { critically evaluates and } \\
\text { responsibly shares media } \\
\text { content online }\end{array}$ \\
\hline $\begin{array}{l}\text { think about creating a picture } \\
\text { of themselves in online } \\
\text { communication }\end{array}$ & $\begin{array}{l}\text { Rules of good behaviour } \\
\text { and communication on the } \\
\text { Internet }^{8}\end{array}$ & applies the rules of netiquette \\
\hline $\begin{array}{l}\text { read, listen and use selected } \\
\text { works of literature for } \\
\text { personal growth and } \\
\text { development. }\end{array}$ & Artistic literature & $\begin{array}{l}\text { actively participates in various } \\
\text { activities for the development of } \\
\text { the reading culture and the taste } \\
\text { of the reader }\end{array}$ \\
\hline
\end{tabular}

Aims and contents of KIMP in the third cycle (6th, 7th, and 8th grade Elementary school)

\begin{tabular}{|c|c|c|}
\hline Specific objectives & Contents & Outcomes / Expectations \\
\hline $\begin{array}{l}\text { Students will: } \\
\text { use known sources of } \\
\text { information and meet new } \\
\text { ones to find and manage } \\
\text { information }\end{array}$ & $\begin{array}{l}\text { Sources of information for } \\
\text { general, special and current } \\
\text { informing, referent collection } \\
\text { in the library, UDC, } \\
\text { periodicals, web pages and } \\
\text { catalogues of available } \\
\text { libraries, museums, } \\
\text { institutions }\end{array}$ & $\begin{array}{l}\text { The student: } \\
\text {. determines which information } \\
\text { is needed, searches and } \\
\text { selects different sources } \\
\cdot \quad \text { analyses and evaluates } \\
\text { information } \\
\text { connects information with } \\
\text { existing ones } \\
\text { uses and shares information } \\
\text { respecting intellectual } \\
\text { property }\end{array}$ \\
\hline
\end{tabular}

\footnotetext{
${ }^{7}$ Topic Hidden advertising is common in media education. It is addressed by experts on the Media Literacy website who published the Handbook on Hidden Advertising. Available at https://www.medijskapismenost.hr/wp-content/uploads/2019/04/Closed-oglas\%CC\%8Cavanje.pdf

${ }^{8}$ Self-respect and respecting others in the virtual world are a topic for media professionals. Numerous suggestions can be found at https://www.medijskapismenost.hr/wp-content/uploads/2019/04/Postivanje-self-i-drugih-u-virtualnom-svijetu.pdf.
} 


\begin{tabular}{|c|c|c|}
\hline $\begin{array}{l}\text { use online library catalogues } \\
\text { when creating individual } \\
\text { student work }\end{array}$ & $\begin{array}{l}\text { Online library catalogues } \\
\text { (public, scientific, national } \\
\text { library); note, abstract }\end{array}$ & $\begin{array}{l}\text { the student searches library } \\
\text { collections through an } \\
\text { e-catalogue } \\
\text { recounts in his own words } \\
\text { writes notes } \\
\text { writes a summary }\end{array}$ \\
\hline $\begin{array}{l}\text { will be introduced to the rules } \\
\text { for citing different sources of } \\
\text { information }\end{array}$ & $\begin{array}{l}\text { Citation of sources: book, } \\
\text { journal article, reference in a } \\
\text { manual collection, simple } \\
\text { electronic sources }\end{array}$ & $\begin{array}{l}\text { uses the citation rules of the } \\
\text { sources }\end{array}$ \\
\hline $\begin{array}{l}\text { become familiar with the } \\
\text { research process, simply } \\
\text { searching for information in a } \\
\text { digital environment } \\
\text { know the criteria of evaluation } \\
\text { and selection of necessary } \\
\text { information among those } \\
\text { found } \\
\text { apply the rules of responsible } \\
\text { use of the information }\end{array}$ & $\begin{array}{l}\text { Simple research (e.g. BIG 6) } \\
\text { The rule of three sources } \\
\text { Evaluation of information } \\
\text { sources } \\
\text { Responsible information } \\
\text { management }\end{array}$ & $\begin{array}{l}\text { performs simple research on } \\
\text { their own and complex } \\
\text { research with the help of the } \\
\text { teacher } \\
\text { performs a simple } \\
\text { information search on their } \\
\text { own } \\
\text { independently or with the } \\
\text { help of the teacher evaluates } \\
\text { and selects the necessary } \\
\text { information from the gathered } \\
\text { ones } \\
\text { independently or with the } \\
\text { teacher's help responsibly } \\
\text { manages the collected } \\
\text { information }\end{array}$ \\
\hline $\begin{array}{l}\text { familiarise themselves with a } \\
\text { practical guide to independent } \\
\text { studying in a digital } \\
\text { environment }\end{array}$ & $\begin{array}{l}\text { Virtual classroom (Five for } \\
\text { the Net) }\end{array}$ & $\begin{array}{l}\text { the student uses online } \\
\text { practical guides as a way to } \\
\text { learn new content } \\
\text { independently }\end{array}$ \\
\hline $\begin{array}{l}\text { get to know the most common } \\
\text { stereotypes and prejudices in } \\
\text { the media }\end{array}$ & Stereotypes in the media ${ }^{10}$ & $\begin{array}{l}\text { recognises the most common } \\
\text { stereotypes in the media }\end{array}$ \\
\hline
\end{tabular}

\footnotetext{
${ }^{9}$ In addition to the topic of online learning, students can be introduced to Virtual Classroom Five for the Net. Module 4 (ages 7 and 8 ) is appropriate for their age. Available at http://kurikulum.petzanet.hr/VirtualUcionica/Modul/4

${ }^{10}$ Media Stereotypes is addressed by media literacy experts on the Media Literacy website. Various contents available at https://www.medijskapismenost.hr/recognize-stereotypes/
} 


\begin{tabular}{|l|l|l|}
\hline $\begin{array}{l}\text { become aware of the rules of } \\
\text { conduct and communication } \\
\text { in the virtual world }\end{array}$ & $\begin{array}{l}\text { Self-respect and respecting } \\
\text { others in the virtual world }\end{array}$ & $\begin{array}{l}\text { self-respect and respects } \\
\text { others in the physical and } \\
\text { virtual world }\end{array}$ \\
\hline $\begin{array}{l}\text { learn about the types of } \\
\text { cyberbullying on the internet } \\
\text { and how to protect themselves }\end{array}$ & $\begin{array}{l}\text { Electronic violence } \\
\text { Unacceptable behaviour on } \\
\text { the internet }\end{array}$ & $\begin{array}{l}\text { proposes and acts on } \\
\text { guidelines for protection } \\
\text { against cyberbullying }\end{array}$ \\
\hline $\begin{array}{l}\text { proposes and acts on } \\
\text { guidelines for protection } \\
\text { against cyberbullying }\end{array}$ & $\begin{array}{l}\text { Creation and media: poster, } \\
\text { placard, video, broadcast, } \\
\text { radio story, promotional } \\
\text { message, etc. }\end{array}$ & $\cdot \begin{array}{l}\text { independently creates a media } \\
\text { message of their choice }\end{array}$ \\
\hline $\begin{array}{l}\text { read, listen and use freely } \\
\text { selected literature for personal } \\
\text { growth and development. }\end{array}$ & Literature & $\begin{array}{l}\text { organises and runs various } \\
\text { forms of literary events. }\end{array}$ \\
\hline
\end{tabular}

\section{Aims and contents of KIMP in the fourth cycle (1st and 2nd grade High school)}

\begin{tabular}{|l|l|l|}
\hline Specific objectives & Contents & Outcomes / Expectations \\
\hline $\begin{array}{l}\text { Students will: } \\
\text { space and rules for using the } \\
\text { school library }\end{array}$ & $\begin{array}{l}\text { Library, fund, opening hours, } \\
\text { school library rules and } \\
\text { regulations, loan rules, } \\
\text { material placement, website }\end{array}$ & $\begin{array}{l}\text { The student: } \\
\text { gets to know the library space, } \\
\text { stock and book placement on } \\
\text { shelves } \\
\text { independently finds the book } \\
\text { he or she wants according to } \\
\text { the signature } \\
\text { explains the importance of } \\
\text { UDC tags } \\
\text { familiarises himself/herself } \\
\text { with library lending rules and } \\
\text { rules of conduct } \\
\text { uses the school library website }\end{array}$ \\
\hline $\begin{array}{l}\text { expand their knowledge of } \\
\text { the reference collection in a } \\
\text { variety of media }\end{array}$ & $\begin{array}{l}\text { Printed and online reference } \\
\text { material }\end{array}$ & $\begin{array}{l}\text { uses a reference collection on } \\
\text { different media } \\
\text { knows the purpose of tertiary } \\
\text { sources of information } \\
\text { finds, selects and applies } \\
\text { information }\end{array}$ \\
\hline
\end{tabular}

\footnotetext{
${ }^{11}$ Content for students in grades $5-8$ on the Media Literacy website. Available at https://www.medijskapismenost.hr/wp-content/uploads/2019/04/Postivanje-sebe-i-drugih-u-virtualnom-svijetu.pdf
} 


\begin{tabular}{|c|c|c|}
\hline $\begin{array}{l}\text { autonomously search online } \\
\text { catalogues of different types } \\
\text { of libraries }\end{array}$ & $\begin{array}{l}\text { Online catalogues of } \\
\text { different types of libraries }\end{array}$ & $\begin{array}{l}\text { searches online catalogues of } \\
\text { different libraries } \\
\text { searches catalogues by author, } \\
\text { title, subject, keywords, ISBN, } \\
\text { ISSN, publisher }\end{array}$ \\
\hline $\begin{array}{l}\text { expand their knowledge of } \\
\text { copyright and citation rules }\end{array}$ & $\begin{array}{l}\text { Copyright (adjusted base of } \\
\text { the Law on Copyright and } \\
\text { Related Rights ) } \\
\text { Plagiarism } \\
\text { Paraphrase } \\
\text { Citation }\end{array}$ & $\begin{array}{l}\text { respects copyright } \\
\text { interprets the legal framework } \\
\text { for intellectual property } \\
\text { protection } \\
\text { comments on ethical and legal } \\
\text { issues related to the } \\
\text { application of the law } \\
\text { uses global copyright and fair } \\
\text { use labels } \\
\text { knows the term public domain } \\
\text { or the public good and the } \\
\text { meaning of the Creative } \\
\text { Commons license }\end{array}$ \\
\hline $\begin{array}{l}\text { autonomously produce a } \\
\text { seminar paper }\end{array}$ & $\begin{array}{l}\text { Seminar paper } \\
\text { Composition and elements of } \\
\text { work } \\
\text { Keywords, citation, footnote }\end{array}$ & $\begin{array}{l}\text { finds the material needed to } \\
\text { produce a seminar paper } \\
\text { knows the structure of } \\
\text { seminar work } \\
\text {. } \\
\text { creates work autonomously }\end{array}$ \\
\hline $\begin{array}{l}\text { recognize the need for } \\
\text { information, deliberate about } \\
\text { the types of information on } \\
\text { the internet, conduct an } \\
\text { independent search, select } \\
\text { information and critically } \\
\text { evaluate it }\end{array}$ & $\begin{array}{l}\text { Internet } \\
\text { Information } \\
\text { Search strategies } \\
\begin{array}{l}\text { Information evaluation } \\
\text { criteria }\end{array}\end{array}$ & $\begin{array}{l}\text { uses the Internet as a source of } \\
\text { information } \\
\text { organizes, analyses, interprets } \\
\text { and evaluates information } \\
\text { from the Internet } \\
\text { critically evaluates } \\
\text { information sources and } \\
\text { search results independently } \\
\text { develops the skill of selecting } \\
\text { quality information according } \\
\text { to evaluation criteria } \\
\text { identifies relevant web pages }\end{array}$ \\
\hline
\end{tabular}




\begin{tabular}{|c|c|c|}
\hline $\begin{array}{l}\text { independently analyse the } \\
\text { impact of media texts on the } \\
\text { daily life of the recipient } \\
\text { analyse current media } \\
\text { messages } \\
\text { create their own media } \\
\text { message }\end{array}$ & $\begin{array}{l}\text { Different types of media and } \\
\text { media messages } \\
\text { The impact of media } \\
\text { messages on the recipient } \\
\text { Creating their own media } \\
\text { message }\end{array}$ & $\begin{array}{l}\text { explains what media is } \\
\text { distinguishes between } \\
\text { different types of media } \\
\text { messages } \\
\text { knows the commercial nature } \\
\text { of the media } \\
\text { critically evaluate media } \\
\text { messages } \\
\text { detects false and covert } \\
\text { messages } \\
\text { explains complex } \\
\text { relationships between } \\
\text { audiences and media content } \\
\text { generates a media message } \\
\text { independently and sends via } \\
\text { media }\end{array}$ \\
\hline $\begin{array}{l}\text { read literature for personal } \\
\text { growth and development and } \\
\text { for leisure }\end{array}$ & Short story & $\begin{array}{l}\text { actively listens and comments } \\
\text { reading material } \\
\text { deepens knowledge, develops } \\
\text { moral sensitivity, strengthens } \\
\text { self-confidence } \\
\text {. } \quad \text { strengthens active listening } \\
\text { competencies } \\
\text { strengthens reading and } \\
\text { speaking skills } \\
\text { develops a sensibility for } \\
\text { literature }\end{array}$ \\
\hline $\begin{array}{l}\text { participate in a poetry } \\
\text { bibliotherapy workshop }\end{array}$ & $\begin{array}{l}\text { Literary text of your choice } \\
\text { Presentation } \\
\text { Selected texts }\end{array}$ & $\begin{array}{l}\text { reads actively and critically } \\
\text { independently selects and } \\
\text { presents a book to read for } \\
\text { pleasure } \\
\text { highlights details that } \\
\text { particularly impressed and } \\
\text { were thought-provoking } \\
\text { supports his or her opinion } \\
\text { and views with examples } \\
\text { explains what he/she enjoys } \\
\text { reading }\end{array}$ \\
\hline
\end{tabular}




\begin{tabular}{|c|c|c|}
\hline $\begin{array}{l}\text { organize literary encounter } \\
\text { with the writer }\end{array}$ & Meet and talk with a writer & $\begin{array}{l}\text { talks with the writer and asks } \\
\text { questions } \\
\text { develops communication } \\
\text { skills } \\
\text { develops aesthetic sensitivity } \\
\text { and reveals the artistic value } \\
\text { of the literature work } \\
\text { develops organisational skills }\end{array}$ \\
\hline $\begin{array}{l}\text { participate in the presentation } \\
\text { of the book }\end{array}$ & $\begin{array}{l}\text { A book for young people } \\
\text { selected by the librarian } \\
\text { Workshop }\end{array}$ & $\begin{array}{l}\text { develops active listening skills } \\
\text { asks questions related to the } \\
\text { text offered } \\
\text { develops reading and speaking } \\
\text { skills } \\
\text { develops confidence in } \\
\text { expressing one's opinion } \\
\text { respects others } \\
\text {. } \\
\text { develops a reader's taste }\end{array}$ \\
\hline $\begin{array}{l}\text { conduct research in } \\
\text { collaboration with the subject } \\
\text { teacher }\end{array}$ & $\begin{array}{l}\text { Research work according to } \\
\text { the chosen model }\end{array}$ & $\begin{array}{l}\text { autonomously conducts } \\
\text { complex research to solve } \\
\text { problems } \\
\text { performs a complex search of } \\
\text { information } \\
\text { independently evaluates the } \\
\text { process critically, sources and } \\
\text { search results, selects the } \\
\text { necessary information } \\
\text { autonomously and responsibly } \\
\text { organizes the information. }\end{array}$ \\
\hline
\end{tabular}


Aims and contents KIMP in the fifth cycle (3rdand 4thyear High school)

\begin{tabular}{|c|c|c|}
\hline Specified objectives & Contents & Outcomes / Expectations \\
\hline $\begin{array}{l}\text { Students will: } \\
\text { use the websites of the } \\
\text { different types of libraries } \\
\text { and their specific digital } \\
\text { collections }\end{array}$ & $\begin{array}{l}\text { Network websites and } \\
\text { digital collections } \\
\text { Digitized library, archive } \\
\text { and museum collections }\end{array}$ & $\begin{array}{l}\text { The student: } \\
\text { - uses websites and digital } \\
\text { collections of various } \\
\text { institutions in Croatia and } \\
\text { abroad } \\
\text { - understands the importance of } \\
\text { preserving cultural heritage } \\
\text { with the help of digitized } \\
\text { materials } \\
\text { - } \\
\text { recognises websites of libraries } \\
\text { and heritage institutions as } \\
\text { reliable sources of information }\end{array}$ \\
\hline $\begin{array}{l}\text { apply appropriate activities in } \\
\text { the digital environment }\end{array}$ & $\begin{array}{l}\text { Social networks } \\
\text { Internet violence } \\
\text { Digital identity protection } \\
\text { Netiquette }\end{array}$ & $\begin{array}{l}\text { - communicates independently in } \\
\text { a secure digital environment } \\
\text { recognises risks in } \\
\text { communicating with strangers } \\
\text { - takes responsibility for own } \\
\text { security in the digital } \\
\text { environment } \\
\text { - takes care of the } \\
\text { appropriateness of their } \\
\text { electronic identity } \\
\text { - eliminates the influence of } \\
\text { stereotypes and prejudices in } \\
\text { communication with members } \\
\text { of other cultures } \\
\text { - respects different points of view } \\
\text { and develops a positive attitude } \\
\text { towards members of other } \\
\text { cultures } \\
\text { promotes tolerance }\end{array}$ \\
\hline
\end{tabular}




\begin{tabular}{|c|c|c|}
\hline $\begin{array}{l}\text { critically evaluate the impact } \\
\text { of media texts onto the } \\
\text { experience of reality and the } \\
\text { shaping of the recipients' } \\
\text { worldviews } \\
\text { develop awareness of the } \\
\text { need to protect against } \\
\text { harmful media influences, } \\
\text { identify examples of human } \\
\text { rights violations in media } \\
\text { texts and advertising } \\
\text { messages } \\
\text { identify fake news } \\
\text { independently }\end{array}$ & $\begin{array}{l}\text { Print and electronic media } \\
\text { Protection of Human Rights } \\
\text { in the media }\end{array}$ & $\begin{array}{l}\text { - critically assess different } \\
\text { actions in public, commercial } \\
\text { and non-profit media to shape } \\
\text { their own experience of reality } \\
\text { and identity } \\
\text { compares the independence and } \\
\text { censorship of media messages } \\
\text { in media texts } \\
\text { - explains the content of } \\
\text { commercial media messages } \\
\text { describes the social and } \\
\text { aesthetic value of media text } \\
\text { compares different media texts } \\
\text { and critically assesses how } \\
\text { information, ideas, attitudes and } \\
\text { opinions are presented and how } \\
\text { they influence the experience of } \\
\text { reality and the identity of the } \\
\text { recipient in terms of age, gender } \\
\text { and cultural context } \\
\text { recognises and distinguishes } \\
\text { fake news from true ones }\end{array}$ \\
\hline $\begin{array}{l}\text { get acquainted with the terms } \\
\text { bibliography and reference } \\
\text { list } \\
\text { independently create a } \\
\text { reference list at the end of the } \\
\text { final paper }\end{array}$ & $\begin{array}{l}\text { Bibliography } \\
\text { Reference list } \\
\text { Final and seminar work in } \\
\text { vocational schools, } \\
\text { Seminar work in high } \\
\text { schools - gymnasiums }\end{array}$ & $\begin{array}{l}\text { distinguishes the bibliography } \\
\text { from the reference list } \\
\text { - autonomously compiles a } \\
\text { reference list according to } \\
\text { specific standards }\end{array}$ \\
\hline $\begin{array}{l}\text { autonomously write a job } \\
\text { application and professional } \\
\text { resume }(\mathrm{CV})\end{array}$ & $\begin{array}{l}\text { Job application } \\
\text { CV (e.g. Europass) }\end{array}$ & $\begin{array}{l}\text { - creates new content } \\
\text { autonomously }\end{array}$ \\
\hline
\end{tabular}




\begin{tabular}{|c|c|c|}
\hline $\begin{array}{l}\text { get acquainted with the } \\
\text { composition and production } \\
\text { of the } \\
\text { graduate seminar paper or } \\
\text { dissertation }\end{array}$ & $\begin{array}{l}\text { Composition and elements } \\
\text { of graduation work } \\
\text { Citation } \\
\text { Paraphrasing } \\
\text { plagiary } \\
\text { Citing literature }\end{array}$ & $\begin{array}{l}\text { analyses and evaluates } \\
\text { examples of graduation (final) } \\
\text { papers } \\
\text { applies knowledge acquired } \\
\text { through KIMP's education } \\
\text { while writing graduation (final) } \\
\text { papers } \\
\text { applies ethical regulations } \\
\text { when interpreting and citing } \\
\text { another people's work }\end{array}$ \\
\hline $\begin{array}{l}\text { create a book report DOS } \\
\text { using digital tools in } \\
\text { accessing a literary work }\end{array}$ & $\begin{array}{l}\text { Book reading DOS (digital } \\
\text { educational content) }\end{array}$ & $\begin{array}{l}\text { autonomously or in } \\
\text { collaboration with colleagues } \\
\text { creates and shares new ideas } \\
\text { and works using information } \\
\text { and communication technology } \\
\text { independently creates new } \\
\text { content }\end{array}$ \\
\hline $\begin{array}{l}\text { take part in a literary, film } \\
\text { panel or theatre performance }\end{array}$ & $\begin{array}{l}\text { Literary panel } \\
\text { Film panel } \\
\text { Theatre play (or interactive } \\
\text { theatre forum) }\end{array}$ & $\begin{array}{l}\text { observes and analyses read text, } \\
\text { film or theatre play } \\
\text { expresses his artistic and } \\
\text { aesthetic experience of the work } \\
\text { distinguishes between the } \\
\text { aesthetics of high culture and } \\
\text { the so-called kitsch in popular } \\
\text { culture }\end{array}$ \\
\hline $\begin{array}{l}\text { make a public speech or } \\
\text { present a literary work. }\end{array}$ & $\begin{array}{l}\text { Public speech } \\
\text { Presents literature work }\end{array}$ & $\begin{array}{l}\text { independently exhibits and } \\
\text { presents a literary work } \\
\text { critically evaluates what has been } \\
\text { read } \\
\text { arguments his view of the read } \\
\text { literary work } \\
\text { develops research, cognitive and } \\
\text { creative activities } \\
\text { making efforts to awaken an } \\
\text { interest in reading in his peers. }\end{array}$ \\
\hline
\end{tabular}

\section{Learning and teaching KIMP}

The realisation of the set objectives proposed in the librarian programme framework KIMP puts students in situations of meaningful learning and requires the connection of content and strategy research learning. The purpose is to develop an environment in which the student becomes information and media literate with developed reading habits and is capable of coping with all types of libraries, as well as handling information outside the institutions, regardless of which type of high school he/she finished at his/her formal education. 
The role of the school librarian is in pursuing various forms of cooperation with teachers, as well as support in teaching, parallel teaching, teaching complementarity, teaching in teams (Schultz-Jones \& Oberg, 2016), joint planning and research work, cooperative learning in a network environment and encourage reading. The school librarian in cooperation with teachers plans to connect and implement KIMP topics with content of subject curricula. The evaluation of programme outcomes is formatively conducted by the school librarian (evaluation as teaching and learning) in order to monitor students' progress in the acquisition of competences, while summative evaluation is carried out by the teacher whose expected outcomes are included in the assessment criteria.

\section{Conclusion}

The draft framework for the programme of library, information and media literacy education and promoting reading [KIMP] presented in this paper brings a unified and modernised concise version of library and information fields for primary schools and an optional Proposal of library-information and media education (KIMOO) to high school (Telesmanić et al., 2017) as revised at the present time in the Republic of Croatia tailored framework that provides learning objectives and teaching content and learning outcomes.

The implementation of the proposed programme KIMP allows the vertical continuity of educational outcomes of two new curricula areas - Learning to learn and Use of information and communication technologies, published in 2019, as well as other subject curricula, especially the Croatian language. The framework for the programme connects former content related to library, information and media literacy in primary and secondary schools, and with the development and application of different learning strategies prepares students of all ages to continue their education, elementary to high school, high school to university, and is the foundation for lifelong learning. School librarians support the students and teachers in finding, evaluating and using information resources, which contribute to the development of different forms of literacy, especially information, reading, media and digital. Accordingly, learning objectives are determined, as are content and learning outcomes, which are visible as possible correlation and joint planning of teachers and librarians, linking topics and outcomes proposed in the programme with amenities, outcomes and expectations of the other subject and curricular areas, including collaborative teaching.

It is expected that the student who has acquired competencies covered by the proposed framework KIMP will be able to safely and confidently navigate through print and digital sources and a variety of media. Most importantly, he will be able to manage, analyse, critically evaluate and ethically use different sources and selected information, create and share new content and gain reading competences desirable and necessary for living in a globally connected world of the $21^{\text {st }}$ century.

\section{Abbreviations List}

HNOS - Hrvatski nacionalni obrazovni standard/ Croatian National Education Standard IFLA - The International Federation of Library Associations and Institutions

IKT - informacijska i komunikacijska tehnologija / Information and communication technology KIMOO - knjižnično-informacijski i medijski odgoj i obrazovanje za srednje škole / library- information and media education for high schools

KIMP - knjižnična, informacijska i medijska pismenost i poticanje čitanja / library, information and media literacy education and reading promotion KIP - knjižnično-informacijsko područje; u osnovnim školama / library-information content 
MZOŠ - Ministarstvo znanosti, obrazovanja i športa Republike Hrvatske / Ministry of Science, Education and Sports of the Republic of Croatia

MZO - Ministarstvo znanosti i obrazovanja Republike Hrvatske / Ministry of Science and Education of the Republic of Croatia

NN - National Newspaper, službeni list Republike Hrvatske / National newspapers, Official Gazette of the Republic of Croatia

NOK - Nacionalni okvirni kurikulum / National Framework Curriculum

UNESCO - United Nations Educational, Scientific and Cultural Organisation

\section{REFERENCES}

Government of the Republic of Croatia. (2014). Strategy of Education, Science and Technology.

Retrieved from http://www.kvalifikacije.hr/sites/default/files/news/2018-01/Nacrt-prij

edloga-strategije-obrazovanja-znanosti-i-tehnologije.pdf

Schultz-Jones, B., \& Oberg, D. (Eds.). (2016). IFLA School Library Guidelines. Zagreb: Croatian Library Association.

Lau, J. (2011). Guidelines on Information Literacy for Lifelong Learning. Zagreb: Croatian Library Association.

Republic of Croatia. Ministry of Culture. (2017). National Reading Incentive Strategy for 2017-2022.

Zagreb: Author. Retrieved June 23, 2019, from

https:/www.min-kulture.hr/userdocsimages/NAJNOVIJE\%20NOVOSTI/a/NSPC\%CC\%8C.pdf

Republic of Croatia. Ministry of Science, Education and Sports. (2010). National curriculum framework for pre-school education and general compulsory and secondary education. Retrieved from http://www.azoo.hr/images/stories/dokumenti/Nacionalni_okvirni_kurikulum.pdf

Republic of Croatia. Ministry of Science and Education. (2019). Decision on curriculum development for the cross-curricular topic Use of information and communication technology for primary and secondary schools in the Republic of Croatia (NN 7/2019, 150). Retrieved from https://narodne-novine.nn.hr/clanci/sluzbeni/2019_01_7_150.html

Republic of Croatia. Ministry of Science and Education. (2019). Decision on curriculum development for the cross-curricular theme Learning how to learn for primary and secondary schools in the Republic of Croatia (NN 7/2019, 154). Retrieved from https://narodne-novine.nn.hr/clanci/sluzbeni/2019_01_7_154.html

Republic of Croatia. Ministry of Science and Education. (2019). Decision on adopting the curriculum for the subject of Geography for elementary schools and high schools in the Republic of Croatia (NN 7/2019, 145). Retrieved from https://narodne-novine.nn.hr/clanci/sluzbeni/2019_01_7_145.html

Republic of Croatia. Ministry of Science and Education. (2019). Decision on adopting the curriculum for the English language course for elementary schools and high schools in the Republic of Croatia 
(NN 7/2019, 135). Retrieved from

https://narodne-novine.nn.hr/clanci/sluzbeni/2019_01_7_139.html

Republic of Croatia. Ministry of Science and Education. (2019). Decision on adopting the curriculum for the English language course for vocational secondary schools at level 4.2. in Republic of Croatia (NN 10/2019, 124). Retrieved from https://narodne-novine.nn.hr/clanci/sluzbeni/2019_01_10_211.html

Republic of Croatia. Ministry of Science and Education. (2019). Decision on adopting the curriculum for the Croatian language course for elementary schools and high schools in the Republic of Croatia (NN 10/2019, 215). Retrieved from https://narodne-novine.nn.hr/clanci/sluzbeni/2019_01_10_215.html

Republic of Croatia. Ministry of Science and Education. (2019). Decision on adopting the curriculum for the Croatian language course for secondary vocational schools at level 4.2. in Republic of Croatia (NN 10/2019, 214). Retrieved from https://narodne-novine.nn.hr/clanci/sluzbeni/2019_01_10_214.html

Republic of Croatia. Ministry of Science and Education. (2018). Decision on adopting the curriculum for the subject of Informatics for elementary schools and high schools in the Republic of Croatia (NN 22/2018, 436). Retrieved from https://narodne-novine.nn.hr/clanci/sluzbeni/2018_03_22_436.html

Steinbuch, M. (2010). Preface. In M. Steinbuch (ed), Updates to lessons in high school practice. Library Information Knowledge (pp 7-9). Ljubljana: National Education Institute of the Republic of Slovenia. Retreived from https://www.zrss.si/projektiess/gradiva/posgim/GRA_Knjiznicno_in formacijsko_znanje.pdf

Stričević, I., \& Perić, I. (2019). The significance of information literacy in the digital age: contextualization in the teaching lesson of a school librarian. In I.Perić, A. Saulačić (Eds.), $X X X I$ Spring School of School Librarians of the Republic of Croatia: Šibenik April 8 - 11, 2019 Experimental Associate Librarian Lesson: Proceedings (pp 9-21). Zagreb, Education and Teacher Training Agency. Retrieved from https://www.azoo.hr/photos/izdanja/31-psskrh-1561735564.pdf

Špiranec, S., \& Banek Zorica, M. (2008). Information literacy: theoretical framework and starting points. Zagreb: Institute for information studies Faculty of Humanities and Social Sciences, University of Zagreb.

Telesmanić, T., Grbić, N., Riger-Knez, D., \& Perić, I. (2017). A programme framework for Library-Information and Media Education (KIMOO) in secondary and vocational schools. In A. Saulačić (Ed.), XXIX Spring School of School Librarians of the Republic of Croatia: Trogir April 6-8, 2017 Curriculum of Library Education: The Path to Critical Thinking, Knowledge and Personal Development: Proceedings (pp. 262-273). Zagreb, Education and Teacher Training Agency. Retrieved from https://www.azoo.hr/photos/izdanja/29-skola-knjiznicara-1536871789.p df 
Vican, D., \& Milanović Litre, I. (Eds.). (2006). Curriculum for elementary school. Zagreb: Ministry of Science, Education and Sports of the Republic of Croatia. Retrieved from https://www.azo o.hr/images/AZOO/Ravnatelji/RM/Nastavni_plan_i_program_za_osnovnu_skolu_-_MZOS_2006 _.pdf 


\section{Biographical Note}

Ivana Perić is a school librarian in The Primary school Petra Preradovića, Zadar. She graduated Croatian language and literature, University of Split, and Information Sciences - librarianship, University of Osijek.

Danijela Riger-Knez is a school librarian in The Vocational School for Tourism and Catering in Zadar. She graduated Croatian language and literature, University of Zagreb, and Information Sciences librarianship, Zadar.

Tanja Telesmanić is a school librarian in The Vocational School for Economics, Administration and Trade in Zadar. She graduated Croatian language and literature, University of Split, and Information Sciences - librarianship, University of Osijek.

Mišela Nežić is a school librarian in The Primary school Zadarski otoci - Zadar. She graduated Croatian language and literature, University of Split, and Information Sciences - librarianship, Zadar.

Hajdi Škarica is a school librarian in The High school Franje Petrića Zadar. She graduated Croatian language and literature, University of Split, and Information Sciences - librarianship, University of Osijek. 